\title{
Chilean Reform on Italian Pension System
}

\section{Phillip A Mixon*}

Department of Economics, Troy University, Troy, AZI United States

\begin{abstract}
This paper examines the Italian public pension system reforms and the possibility of switching to a private capitalization system. Currently several countries are experiencing a high level of public debt, and the political debate is gravitating around the reduction of budget deficits and the improvement of public debt as a percentage of GDP ratio. An important part of public expenditure is represented by pension benefits; its amount is constantly increasing due to the architecture of public pension system, which cannot face the change happened in the demographic composition nowadays. I try to use the Chilean experience as a model for the Italian pension system. In the Conclusion, several policies are laid out to help facilitate this transition.
\end{abstract}

Keywords: Chilean pension reform; Italian pension reform; Private pensions

\section{Introduction}

This paper examines the Italian public pension system reforms and the possibility of switching to a private capitalization system. Currently several countries are experiencing a high level of public debt, and the political debate is gravitating around the reduction of budget deficits and the improvement of public debt as a percentage of GDP ratio. An important part of public expenditure is represented by pension benefits; its amount is constantly increasing due to the architecture of public pension system, which cannot face the change happened in the demographic composition nowadays. In the last decades Italy has changed rules regarding pension benefits, aiming to a reduction of expenditures; nonetheless those effort did not produced the expected result and the pension expenditure keeps increasing.

The Italian pension reforms throughout times and its weaknesses, Empirical evidence has shown from Chile, which changed its public pension system to a private capitalization one in 1981. The purpose is to identify if a private pension system can be tailored to Italy and which actions must be undertaken in order to manage the transition properly and minimize its impact. The main issues regarding the change regard: the equity between generations and the financial sustainability of the system itself.

\section{Italian Pension System}

The Italian pension system has been changed several times in the last 65 years, and currently it is based on three main pillars:

1. Mandatory public system: has the goal of giving adequate funds in case of injury, illness, death, elderly and involuntary unemployment. This pillar is based on the $38^{\text {th }}$ article of the national Constitution.

2. Complimentary public system: has the goal of integrating the public pension system, based on voluntary savings.

3. Complimentary private system: personal savings administrated by private companies [1].

The mandatory public system is the most important and attracts most of the debates, about possible reforms. After the three main reforms that succeeded over the past years, there are three different calculation methods currently existing; giving Italy a very complicated and unequal treatment system. The oldest one calculates the pension using the retribution method, whereas the most recent is based on the contribution method; a mixed model, based on both methods of calculation also exists. It affects workers that started working during the older system and did not have 18 years of contribution when the 1995 reform was implemented. The retribution method, calculates the amount of the pension based on the average worker's salary multiplied for a previously law established coefficient. On-the-other-hand, the contribution method calculates the amount of the pension benefit based on the total amount of savings during the worker's entire career, multiplied for a pre-established coefficient based on the retirement age. Savings are adjusted for the GDP growth in the last five years, if there is growth.

The mandatory public system is repartition based; therefore, it is financed by the social contribution paid by both the worker and the employer, to the social care institution called INPS (Istituto Nazionale della Previdenza Sociale). This system is based on the intergenerational deal; in which current workers' pay current retirees, so the next generation is supposed to pay pension to the current working one. In this system there is no capital accumulation, as the funds available for pension are used to pay retirees. In this case INPS collects funds and pays the retirees pension. There is no possibility of market investment as each month there is no available resources to invest [2]. The complimentary system is based on different principles and it is not supposed to substitute the mandatory public system; rather, it is meant to integrate future retiree's pensions. It is predicted that future pensions will be lower due to the reduction of substitution coefficients. This system is capitalization based, it is financed with individual contribution, and therefore it is not mandatory. Funds are then invested in the market and capital accumulation is realized; the complimentary pension system is managed by INPS, too. The third pillar is a private personal retirement plan, offered by banks, private investors or insurance companies. It differs based on the type of plan chosen and it is strictly voluntary and regulated as any financial instrument available on the market. The main difference between this investment and the previous pillar is that one is publicly managed,

*Corresponding author: Phillip A Mixon, Department of Economics, Troy University, Troy, AZI united states, Tel: 3346703140; E-mail: pamixon@troy.edu

Received March 02, 2015; Accepted July 28, 2015; Published August 04, 2015

Citation: Mixon PA (2015) Chilean Reform on Italian Pension System. Bus Eco J 6: 172. doi:10.4172/2151-6219.1000172

Copyright: @ 2015 Mixon PA. This is an open-access article distributed under the terms of the Creative Commons Attribution License, which permits unrestricted use, distribution, and reproduction in any medium, provided the original author and source are credited. 
while the latter is managed by a private organization.

The national pension system after World War II, was a repartition system and retribution based. The system had a high fragmentation, as it guaranteed different benefits for different worker categories (public or private sector), moreover, it guaranteed different retirement age between men and women. A particular case of mismanagement and long-term unsustainability is the baby-pension guaranteed to married women working in the public sector, which could retire after 15 years, 6 months and 1 day of work or any men that could retire after just 20 years of work. Moreover, in a country where career advancements are generally age based, calculating the pension lifetime check with a retribution system based on the average of the last 5-year salaries (up to $80 \%$ of the salaries), lead quickly to questions about the sustainability of the pension system.

The pension system was implemented right after World War II, and it was considered sustainable, based on the demographic composition of the population at that time. Ten workers were available to pay the pension of each retiree. The unemployment level was lower than today, so more workers could pay for the retirees. However, economic and demographic conditions changed, showing the weaknesses of this system.

The first reform of the national pension system happened in 1992, its main motivation is the long-run unsustainability of the expenditure pattern and its impact on GDP. At this time the pension expenditure on GDP is around $13.6 \%$. In 1992 Italy submitted the Maastricht treaty, which created the European Union (EU) and gave light to the monetary unification project of the common European currency, the Euro, realized 10 years later. Each member state is required to respect budget deficit and public debt/GDP levels. Those levels are required in order to create stabilization and unification among countries, so the EU pressed Italy to reduce its public debt and change its expenditure pattern; one of the first sector in which the Italian government acted was the pension system.

In 1992, the so called Amato reform increased the minimum retirement age by 5 years for both men and women; adjusting it to 60 and 55; it increased the minimum contribution age required to be eligible for pension benefit up to 20 years. Finally, it required the calculation of pension, based on the average retribution during the whole working period, rather than the last five years; pensions became exclusively adjusted to inflation [3].

This reform made important changes in the pension system, as it aimed to achieve a better macroeconomic equilibrium, leveling off the pension expenditure as a percentage of GDP. The reform aimed for a better equity, improving the correlation between contribution and future performance. It introduced incentives to voluntary retirement plans. This action was required with extreme urgency, as Italy suddenly increased its default possibilities.

In 1995, another reform was implemented. In this case the main breakthrough is the change to a contribution system, originating a transition phase, in which the pensions are calculated with both the retribution and the contribution system (Mixed system). This increased the correlation between contribution and the effective pension provided. This reform increased the number of workers that are required to pay for the mandatory system, as seasonal and precarious workers are required to pay a contribution of $10 \%$; the future reforms rose until $27.72 \%$ in 2011. It introduced a flexible retirement age varying from 57 to 65 years. The main goal of this reform is to reduce the expenditures. It reviewed the coefficient of substitution (on a 10 year basis), reducing the pension inflation index based on the pension check and giving a better stability to the system. This enlarged the contributors' base. The reform did not apply to those workers that already matured more than 18 years of contribution at the time of implementation, so it will take time to finally switch to the new regime [4].

In 2004, the pension system is reformed again. Workers that use the mixed system are required to have 35 years of contribution and 60 years (increasing those in the next years) or 40 years of contribution. Workers of the private sector are required to be one year older to be eligible. Workers that use the contribution system have been affected too, because the reform raised the minimum required age from 57 to 60 for women and from 60 to 65 for men. The reform allowed workers to retire in just 2 months of the year (January and July), instead of the previous 4 , increasing de facto the working requirement up to a maximum of 9 months [5]. The reform bases its capstones on the EU directives, which explicitly suggest increasing the retirement age to reduce the dependency ratio. As workers delay their retirement, fewer workers are required to pay retirees pension. The increase of retirement age would reduce the expenditure dynamic, meanwhile improving the financial stability of the whole system. It is estimated that increasing the retirement age of at least 3 years, would reduce the yearly pension expenditure by 9 billion Euros ( $0.7 \%$ of GDP).

The reform did not factor in the workers' reaction. Lowering the substitution index will generate lower pensions, and workers are more willing to procrastinate the retirement age; so the elimination of the time window, 57 to 65 , did not create the expected results.

The last pension system reform is dated back to 2011. It introduced the contribution method for every worker since January 2012. It increased the minimum retirement age of 2 years for women workers passing from 60 to 62 years, establishing a rising path that should reach 66 years in 2018, matching the men's retirement age already established at 66 years. This is the result of the European Court of Justice that sanctioned Italy for discriminatory behavior between workers, as women (benefit of a slightly longer life expectancy) could retire earlier than men [6]. The new reform introduces a flexible age span of retirement between 63-70 years for women and between 66-70 for men; requiring 42 years and 1 month of contribution for men, while 41 years and 1 month are required for women. Self-employed workers are required to increase 1 year of their minimum requirements. Workers that reached the minimum contribution, but do not have a minimum legal age can retire with a $2 \%$ penalty reduction for each missing year to the required age [7].

The result of the last implemented policies can be considered positive. Despite the pension spending as a percentage of GDP grew in the last three years, mainly because of the negative GDP growth; it is expected to remain stable in the next three years.

\section{Chile Pension Reform}

The military dictatorship in Chile, implemented several free market reforms throughout its history (1973-1988); one of the main reform regards the pension system. Chile's previous pension system was a payas-you-go system, which became. Pay-as-you-go pension systems are based on the so-called intergenerational deal, in which the working generation pays contribution in order to pay pensions to retirees. This system's main benefit is a quick implementation, as it can give pension benefit to those individuals that are not currently working and did not pay any contribution while working. Pension systems are usually implemented in growing economies, which are usually characterized by a large percentage of young people and a smaller percentage of 
older people. While the economy grows, life expectancy grows, and the fertility rate falls. The society becomes older and the pension system is stressed, requiring larger efforts from the working generation to sustain retirees. This demographic change, mined the overall stability of the pension system, attracted the attention of policymakers. They started questioning its sustainability and how to reduce the overall expenditure, minimizing the possible losses.

Chile's government decided, in 1981, to reform the national Pay-as-you-go pension system, replacing it with a privately funded contribution. Therefore Chile changed from a public pension repartition system, to a private capitalization system. Workers are required to save $10 \%$ of their salary into the private saving account (PSA), managed by Administradora de Fondos de Pensiones (AFP). The pension system embraces all the subordinate workers, in both public and private sector with the exception of the Army, while selfemployed workers can decide whether to join the pension system or not; in the case that they do not, they will not benefit from any future pension benefits.

Workers can voluntarily save more money, up to another $10 \%$ of their salary, in case they want a higher pension or want to retire earlier. Those savings are distinguished from PSA and are called voluntary savings account (VSA), but they are both accredited in the same account and still managed by AFP. Both voluntary and mandatory savings are tax-free.

AFP can insure against the death and disability risk too, requiring to workers a further saving of $3 \%$ of their salary. Chile's government decided to guarantee a minimum pension to any worker that contributed at least for 20 years to a PSA, integrating their savings to a minimum amount, required by law. Finally the reform established the minimum age, to be eligible for pension benefits; 65 years for men and 60 for women. Moreover, workers can keep working beyond the minimum pensionable age. Workers that decide to keep working beyond the minimum legal age are not required to save the mandatory $10 \%$ on PSA, making it more attractive for workers to keep working [8].

Once workers decide to retire, they are faced with two possibilities. They can purchase a private insurance fixed lifetime plan, inflation indexed, from another private insurance company; or they can withdraw, with a fixed periodization, from the pension funds. In case of death, the remaining funds become part of the inheritance. In any case a retiree can withdraw the funds that exceed the lifetime settlement or withdraw funds equal to $70 \%$ of their salary level [8].

In 1988 Chile's government allowed workers that did not reached the minimum legal age to retire if they have at least twenty year of contribution. Moreover, workers can choose a third possible benefit, based on a mixed solution a private insurance lifetime plan and a periodic withdraw from the pension fund.

Despite the fact that government is cut out from the pension system administration, it still plays an important role, determining constraints and obligation to AFP's. AFP's are allowed to manage just one pension fund (collection of funds, investment and administration of benefits), in order to avoid conflict of interest in the case AFP's expand their activities, its sellers must be enrolled in an accredited list of traders constituted by the government. Moreover AFP's are required to comply with liquidity requirements and have several trade limitations, both in the financial instruments they can trade and in the portfolio composition; AFP's rate of return cannot be too skewed compared to the others. Finally the law required AFP's to produce mandatory information, in order to give a better transparency to the whole system. AFP's must inform workers at least three times a year about commission and investment activities; each contributor has a book (libreta), in which they can note every balance change [9].

Chile's government's aim is clear. It wants to create competition, limiting the possible risks. International investors are allowed to operate too, as long as they accomplish the previous requirements stated. The required information should avoid possible collusion or cooperation that can endanger the competition among AFP's. Each worker can invest in a single AFP, with the possibility of changing it a maximum of twice a year; increasing competition for the allocation of available capital. Later, Chile changed some rules. In fact since 1985 AFP's could invest in any kind of stock, and since 1991, AFP's can hold in their portfolio any international financial instrument. The government, therefore, aimed to diversify AFP portfolios in order to reduce their market risk. The previous limitation oriented AFP's to invest in company's bonds and Chilean public debt, which was issued to finance the pensions that were financed with the old pension system. The government was not sure that the AFP's would invest in public debt, and feared a possible international debt, which usually carries higher costs [8].

Despite the complete change to a private capitalization system, the government still finances some pensions. It gives financial support in case any worker with at least 20 years of contribution, but with not enough saved capital, can reach a minimum pension level; the government pays the difference. Workers with less than 20 years of contributions can receive pension benefits (lower than the minimum pension), which are financed with general taxes, called PANSIS [10].

Government plays an important role in managing the transition from the public system to the private system. The transition cost, depend strictly on the economic, social and cultural environment of the country in which the reform happened, making it hard to apply those reforms to other countries. There are some issues that are common to any country that tries to change its pension system [11]. Chile mainly faced three issues: which workers must adopt the new system, how can the government keep the acquired rights and how to finance the previous pension system.

\section{Chile decided to undertake the following actions}

1. Government kept paying pension to those workers that already were retired.

2. Those who already worked when the reform was implemented could choose whether to use the old system or to switch to the new one. In case the worker decided to switch systems, all the past contributions were recognized and they were transferred to private funds.

3. Those who started working after the reform needed to adopt a private pension plan, in order to deplete the old pension system overtime.

It is clear the intention of the Chilean government is to preserve past rights, while changing the pension system [12]. At this point, the most difficult issue of any reform is how to find financial sources. The Chilean government cannot rely on mandatory contribution from workers and employers anymore, in order to finance the cumulated social security deficit. So, it decided to implement different actions to finance the reform [11].

1. Mass privatization and sale of part of the public companies (some of them were bought from private pension funds). 
2. Tax increases. The new required contribution for private funds (10\%) is lower than the old mandatory one (24\%) [13]; part of the difference was used as a temporary tax to finance the current pensions.

3. Public debt increase. Part of the deficit was financed raising public debt, allocated on the market at the current market interest. A big part of it was purchased by private pension funds and used as an asset, accounting for $40 \%$ of the private pension fund's assets.

4. Reduction of public inefficiencies. This process was already started prior the pension reform, and was able to create a budget surplus in the years before the reform, making it easier to operate in future.

5. The predicted increase in salary and Chilean economic growth are expected to increase the total amount of taxes paid, especially the VAT tax.

This system penalizes women, as they have a longer life expectancy and workers with a fast growth in salary [13]. The lack of trust in the old system made $36 \%$ of the workers choose the private system [12].

According to two researchers [13], there was an iniquitous treatment between workers who decided to switch to a private fund and those who did not. Workers that did not change their pension system did not have an increase in pay, while the others have benefitted of an average $10 \%$ income increase.

According to Arrau [2], the way to calculate the bonus to switch from the public to the private system, for the current workers, is based on a coefficient established by the law and not by the market; therefore there can be distortions on contribution levels.

\section{Future Prospective}

After the last implemented reform, future mid-term and longterm scenarios have changed. According to the Italian central bank's (Banca d'Italia) report in 2011, based on the Italian Statistics Institute data (ISTAT) shows that in 2060 the life expectancy will rise by 6.7 years for men and 6.1 years for women, The fertility index will rise to 1.6 (1.42 in 2012) and the migration flow will account for 180,000 yearly units; compared to the current 280,000 . Those estimates clearly picture an older society, with fewer immigrants and a fertility index that is below the substitution level of 2.1. It is very likely that there will be future intervention on this issue again [14]. In 2015, it is forecast a reduction of pension expenditure as a percentage of, because of the retirement age increase and the better macroeconomic conditions, which will lead to savings in expenditures and increase in overall GDP. The pension expenditure is estimated to be the $14.4 \%$ of GDP in 2030. So, the public savings on pension will not be endangered from the negative demographic effect. In the next 15 years, a growth of the pension expenditure on GDP is expected; although, the sustained economic growth, reaching the $15.4 \%$ in 2046 . This growth is mainly imputable to higher pension benefits because, in the decade before people were required to work longer, they saved more contributes, and after retiring they will receive a more generous check, increasing the overall expenditure. Finally, the pension expenditure level will reach the $13.6 \%$ on GDP, mainly because of the ending transition process from the retribution model to the contribution model and the great reduction of the baby boomer generation. The working population will be reduced by 11.6 million people, dropping from 32.5 million in 1996 to 20.9 million in 2050; meanwhile the retiree population rises by 4.5 million people from 12.9 million to 17.4 million [15]. At this point, Italy should have lower pension expenditures than other comparable EU nations, such as Germany, France and Spain. Policymakers have to consider if the pension expenditure as a percentage of GDP, can be considered sustainable, and if better results can be obtained with different pension systems.

Currently, the particularity of the Italian pension crisis, common to several other countries in the European Union, is amplified due to loss of sovereignty of public debt. Before the introduction of the common currency, the Euro, and the creation of the European Central Bank (ECB), each national bank printed money and adopted a national interest policy. Now, the ECB is the only institution empowered to print money. This step is considered a capstone to achieve a financial and economic union among European countries, realizing a better convergence among them. Every European country is represented in the ECB board of trustees, and together they decide the monetary policy to adopt; weakening the national policies and reducing the arbitrary wingspan that was possible in the past when each country had its own national bank. Today countries issue debt in common currency and are not able to print money (as they used to) to repay their debt. This reduces the possibility to repay debt increases worries in the international community and in the financial market over the stability of the country, making debt a more costly solution. It is not a case that the spread, calculated as the difference between any national 10 -year public bond and the same 10 year German public bond (Bund), became a financial market indicator of the healthy state of the national economy.

\section{Problem and Implementation}

The previous analysis of the evolution of the Italian pension system shows the difficulties the system has to face. In just 20 years, there have been five reforms. Despite the fact that the last reform is more longterm oriented, the basis of the system weaknesses have not changed, moreover, the analysis of Banca d'Italia about the long run pension funds expenditure on GDP, shows the same level as it is now. All the effects of the reforms are vanished by the system itself, the situation has less high probability of worsening, but the impossibility of reducing the public expenditure is a failure, which requires policymakers to rethink the pension system.

It is important to identify the public contribution to pension system as a form of tax, with all the deadweight loss implication that it carries. So increasing the required contribution distorts the supply of labor [16]. The intergenerational pension system distorts the labor market, reducing labor offer, in mainly three ways. First, pension systems transfer wealth from the working age to the non-working age, so workers are more willing to reduce their labor offer, closer they get to the retirement age. Second, withdrawals from pension funds start after the retirement age, and they are conditioned by the estimated life expectancy, there can be an incentive system to anticipate retirement. Finally, there can be a gap between contributions paid and pension received; reducing labor supply, incentivizing tax evasion and illegal work [17]. Italy is currently affected by a high level of unemployment, especially among the young population, and the level of mandatory saving required is $33 \%$ for the dependent workers ( $1 / 3$ is paid by the worker and $2 / 3$ is paid by the employer) while $27 \%$ is required for selfemployed.

There are different academic positions about the impact of an intergenerational pension system on savings. Supporters of Ricardo's equivalence theory, in which individuals are altruistic and generation are linked by heritage; pension system would not change savings pattern, as they take in consideration the next generation wealth On-the-other-hand, in the case that the Ricardo equivalence is not 
met; a repartition system changes individual preference on savings, reducing the total savings and therefore reducing the GDP. As the repartition system requires its funders to save the same amount and at the same rate of return, without considering the consumption-savings preferences of each worker and the life-cycle spending pattern [17]. Young workers are the most penalized, as the contribution required is heavier because the salary is generally lower at the beginning of the career, reducing the optimal level of consumption. Because this is the period of life in which the worker needs more funds for his life project, the younger generation spends more than the older one. A modulation of contribution based on lower percentages in the young age, while increasing it for the older one; would distort less the optimal level of consumption and mining in a smaller way the liquidity availability [15]. The switch to a capitalization system would definitely encourage private savings, increasing the capital accumulation and boosting the economic growth.

The only way to avoid deadweight loss issues on pensions seems to be the switch to a capitalization system; this breakthrough would cause an equity problem, as in either way, a generation must pay more of what he received, or receive less of what it paid. In case a repartition system is kept (increasing the level of contribution, with lower pension payment in future), would harm the younger generation while adopting the capitalization system would create financing problems to the retirees. The policymaker already thought about the possibility of changing the repartition system enforcing capitalization one, as it created the second and the third pillar, based on voluntary contribution (One pillar is private while the other is public managed). The scarce adoption of those two alternatives can be imputed to low fiscal incentives that did not attract savers to those programs. The result is that the large majority of the Italian workers still adopt the public mandatory repartition unfunded pension.

Reasons to forgo to a capitalization model, rather than a repartition one, are rooted in several economic studies. In order to analyze the convenience of this system it is important to focus on the new system's costs and to identify the role of the government. A capitalization system is based with intermediaries that collect savings, invest and give returns to subscribers. All this process requires is work and remuneration of capital; companies operating in these activities have operating costs and are profit oriented. Costs and company's profits reduce future performances, discouraging workers to subscribe retirement plans and incentivizing evasion. Public system pension funds have lower costs, but the quality of the service and the lower rate of return must be considered before choosing which system gives actually the best rate of return. There can be regulation on the maximum fees applicable, the variety of investment, the maximum return on investments and the possibility of entrance for foreign investment funds. These regulations would discourage the competition and the attraction for companies, reducing the optimal number of companies and reducing the variety of offer as well. These regulations would not allocate properly, savers among the possible fund administrators, based on the aversions to risk; the result would be a lower rate of return on funds [18]. It is very important to guarantee a high level of competition among funds, switching to a different fund should be easy and not costly; in order to allocate the demand based on the best performers.

If private companies administer the pension funds, basing their choices on free market rules, there is possibility of failure and that the subscriber loses part or all of his savings. Because of this, Chile created a backup fund, financed by the investors, in order to integrate the loss of workers, in case a fund administrator fails. This would create a problem of moral hazard, giving the administrator an incentive to participate in riskier investments [19] shifting the default risk to the collectivity. In a free market scenario, insurance companies can offer policies to workers based on each private fund's default risk.

The main advantage of a capitalization system is the reduction of the political risk. In a repartition system the government can change rules on the contribution level, substitution coefficient and retirement age very quickly, so the matured expectations are sometimes not met. This risk is very important and leads to a gap between the sacrifice required (mandatory saving) and the actual performance obtained risk that increased overtime. The evaluation of this risk is very hard, and it plays an important role when considering strength and weaknesses of the two systems.

It is likely that the pension funds administrator market becomes an oligopoly due to the entry barriers; it is important that the government defends transparency and improves communication between fund administrator and saver. Investors should know what kind of investment the funds forgo, in order to better appreciate the rate of return and better choose their fund. The government should impose minimum levels of communication between the administrator and the investor, giving information about the type and the amount of financial instruments held in the portfolio and its return.

The Chile case showed that managing the transition, requires a gradual approach to a private capitalization system, balancing a proper level of taxation, debt and privatization to finance the transition [8]. Coordinating budget cuts and low increase in taxes, guaranteed a good transition, minimizing risks for both generations. The Italian situation is very different from the Chilean one because of the different time frame, the international economic situation and its internal features. The income taxation is based on different percentages varying from a minimum of $23 \%$ to a maximum of $43 \%$ while the VAT is currently $21 \%$, and it is expected to rise to $22 \%$ in June 2013 . It does not seem sustainable a further increase in taxation. Raising debt does not seem a valid alternative too, as the public debt is $126 \%$ according to Eurostat, while the spread between Italian bonds and German bunds has sharply increased over the last years. The Italian situation is endangered for belonging to the EU, as the adoption of the Euro and the signing of the Maastricht treaty has reduced the autonomy and sovereignty of the national government. With the Maastricht treaty any current member aims to not create budget deficit over $3 \%$ and to stabilize the level of public debt to $60 \%$ of the GDP [20]. Despite there is no formal penalty for not forgoing to those laws, it is not possible for the Italian government to raise additional debt. The adoption of the common currency Euro and using a common monetary policy does not allow the national bank to decide the money offer and decide the cost of money. In the past the national bank used to cut interest rates to become more competitive on the worldwide market, attracting more international investments and boosting the export level; basically it used to expand the demand for the national goods and services. A possible way to finance the transition is the privatization of some public sector activities, reducing the total spending. The Italian situation is tougher than the Chilean one as it operates with a current budget deficit, while Chile realized a surplus in the years before implementing its reforms.

In order to be successful, the government should prevent new workers to adopt the repartition system and decide whether current workers can switch to the new capitalization system; in this case it is very important to find out which part of the contribution can become a part of the new constituted fund. In any case the government has to raise taxes to keep financing the previous pension, but this must 
consider that the abandon of the mandatory social contribution, would reduce the cost of labor expanding the economy, augmenting the number of workers and increasing the overall tax revenue.

Government must consider also, that in case of private decision about the level of savings, there can be some workers that decide to not save part of their salaries. Chile decided to give a minimum retirement or integrate private funds that would not reach a minimum standard. This kind of intervention can create a moral hazard problem, as some workers could decide to not save part of their salaries because the government would still guarantee a pension. This behavior happens because long-term benefits are not perceived as short term ones.

Another important variable, when considering transition costs, is the amount of retirees per worker that can change the horizon for the transition and its total amount. Italy had 7 retirees for every 10 workers. The Chilean ratio was better than the current Italian one, so the transition had a shorter time frame. It is estimated that after the 1995 Italian pension reform, that switched from a retribution based system to a contribution based one, the first pension calculated and paid with just the new system will take place in between 2030-2040 [14]. So changing from a repartition system to a contribution one, would have benefits postponed in the future and can be hard to properly estimate. Anyway the current demographic pattern seems to be irreconcilable and unsustainable; therefore incentivizing the private capitalization system looks like a good alternative, but raises the problem of how to finance the current retirees.

Italy has a unique feature that no other country has; each dependent worker is required to save a fixed amount of his salary, throughout their career, that is recognized to the worker after the expiration of the working contract (in case of firing or retirement), called Trattamento di Fine Rapporto (TFR). The TFR is saved every year in the employer account, the savings are inflation indexed and whenever the working contract expires, the employer must refund the worker. TFR yearly saving is $7.4 \%$ of the salary and this level is established by the law [1]. These funds can be directed to private administrators, constituting a fund, instead of being kept in the company; so the TFR can earn a market return, without requiring additional sacrifices to workers. This consideration would exclude self-employed workers that do not have a TFR

A possible solution to finance current retirees' pension, would be to still require a reduced contribution, managed by the public INPS, from workers, guaranteeing them a public minimum pension that will be financed in part by the working generation and in part by the general taxation. This would avoid a big shock in public budgeting, gradually reducing the public mandatory system while switching to a capitalization system, but this process still requires generations to see the actual results.

\section{Conclusion}

The change in the demographic and economic conditions lead the public pension system, based on the intergenerational deal, to a longterm financial unsustainability. Currently, the Italian government is facing the problem of reducing public expenditure, and one of the main reforms regards the pension system. The Chile's case has evidenced that switching from a public repartition based system to a private capitalization system is possible. Moreover, Chile's case showed the issues and the transition costs associated to the change.

Transition costs and the preservation of equity among generations are key components, when evaluating the change and the actions to undertake. Managing the transition period is very important as it determines which generation carries the costs associated with the transition. Italy has a different demographic composition, budget deficit, public debt and economic situation than Chile, when the reform was implemented; but a change is possible and it would require different actions and time. In order to maintain equity, the transition can be managed requiring a minimum public pension funded with the general taxation to pay pension to retirees; while current workers start saving their pension calculated with the capitalization system. The level of the public pension is reduced for the future generation, in order to achieve a perfect transition to a private capitalization system. In the Italian case is very important to emphasize the second and third pillar, that were already allowed by the law, but did not received enough funds from workers because of the scarce incentives given them, and the high benefit derived from the public pensions, which are calculated using the repartition system.

\section{References}

1. Pizzuti FR (2005) Report on the Welfare State. UTET Turin, last.

2. Arrau $P$ (1991) The Chilean pension reform and financing during the transicionCollecion sul Studies CIEPLAN 32: 5-44.

3. D Lgs (1992) n . 503 concerning rules for the adjustment of the social security system for workers of private and public , in accordance with Article 3 of Law 23 October 1992 , no. 421

4. $L(1995)$ n. 335 concerning the reform of the pension system and mandatory complementary.

5. $L(2004) n .243$ regarding New provisions on access to a retirement pension in the pay system and mixed and the old-age pension in the contributory system.

6. Sentenza (2008) ( the Court of Justice of the European Union CJEU ) the C-46/07 Failure to fulfill obligations-Art. 141 EC-Social policy-Equal pay fo male and female workers-Concept of retribuzione- retirement scheme for civil servants.

7. $L(2012) n$. 135 concerning urgent provisions for the revision of public spending with invariance of services to citizens.

8. Bordignon M, Ambrosiano MF (2002) Pensions: the Chilean case Extract thesis Catholic University of the Sacred Heart

9. Feldstein M (1998) Privatizing social security. University of Chicago Press

10. Diamond P (1993) Privatization of social security: Lessons from Chile (No. w4510). National Bureau of Economic Research.

11. World Bank (1994) Averting the old age crisis; policies to protect the old and promote growth. Oxford University Press, New York

12. Balduzzi $P$ (2000) Unfunded pension and capitalization : the Chilean case and the implications for Italy

13. Diamond PA, e Valdes-Prieto S (1994) Social Security Reforms, in Bosworth BP, Dornbush R e Laban, $\mathrm{R}$.

14. Presidency of the Council of Ministers (2011) Document Economic and Financial Analysis and Trends in Public Finance.

15. Fornero Elsa, Onorato Castellino (2001) The reform of the Italian pension system . " II Mulino, Bologna

16. Kaplow L (2006) Myopia and the effects of social security and capital taxation on labor supply (No. w12452). National Bureau of Economic Research.

17. Bonasia M (2003) The reform of social security systems : the theoretical and political debate. DES (Department of Economic Studies), University of Naples Parthenope Italy Working Papers.

18. Edwards S (1998) The Chilean pension reform: A pioneering program. In Privatizing social security (33-62). University of Chicago Press.

19. Franco D, Marè M (2002) Pensions : the economy and policy reforms. Review of economic policy 92: 197-276.

20. Pasinetti LL (1998) The myth (or folly) of the 3\% deficit/GDP Maastricht 'parameter'. Cambridge Journal of Economics 22: 103-116. 